\title{
HUMANIZAÇÃO DOS CUIDADOS EM SAÚDE: CONCEITOS, DILEMAS E PRÁTICAS ${ }^{1}$
}

\author{
CAETANO, Vitor Nunes ${ }^{2}$
}

Humanização e desumanização. Muito embora esses termos guardem íntima relação com certos fenômenos do meio educacional, estranhamente, não fazem parte do rol de palavras mais frequentemente utilizadas por professores, para conferir sentido ao que vivenciam na esfera escolar ${ }^{3}$. No entanto, a humanização, desde os anos 1970, vem se consolidando como um importante objeto de discussão no campo da saúde pela via do cuidar.

O livro, HUMANIZAÇÃO DOS CUIDADOS EM SAÚDE: CONCEITOS, DILEMAS E PRÁTICAS, organizado pela pesquisadora e professora Suely F. Deslandes apresenta, nas palavras da autora, um conjunto de textos que se propõem ao aprofundamento crítico da noção / diretriz humanização, utilizado para o norteamento de iniciativas, discursos e mesmo de uma política nacional promovida pelo Ministério da saúde, no campo da humanização da assistência.

Prefaciado pela pesquisadora Maria Cecília de Souza Minayo, o livro, dividido em três capítulos, conta com a participação de 21 especialistas, que se revesam na autoria de 16 textos da obra. Apresentando em sua parte primeira um conjunto de oito artigos reunidos sob o enfoque da "Humanização dos cuidados: explorando conceitos e conexões disciplinares". Podemos destacar aqui o texto "Humanização: revisitando o conceito a partir da sociologia médica", escrito por Suely Deslandes, que nos oferece os elementos chaves para a compreensão e pertinência de uma discussão sobre humanização, a partir da identificação do caráter humanizante e desumanizante presente nas práticas relacionadas aos cuidados em saúde. Os demais colaboradores trazem a partir das especificidades do campo, contribuições ricas ao aspecto referencial do tema.

Em sua segunda parte, "Humanização nos cuidados de saúde da criança", quatro artigos trazem reflexões sobre aspectos humanizadores e desumanizadores, relativos às práticas médicas direcionadas aos pacientes infantis. Um dos textos, aborda os processos que envolvem a criança sob cuidados médicos, seus familiares e o hospital onde ela é atendida; em outro temos a reflexão sobre os desafios postos, aos cuidados de crianças internadas em UTI's Neonatais; discutindo a importância do brincar no processo de

1 Humanização dos cuidados em saúde: conceitos, dilemas e práticas. DESLANDES, S. F., organizadora. Rio de Janeiro: Fiocruz; 2011.

2 Mestre em Ensino de Educação Básica - PPGEB/CAp-UERJ, Esp. Informática Aplicada a Educação - FTE Souza Marques, Esp. Mídias na Educação - UFRJ, Prof. I - E.M Mozart Lago/ 5aCRE/ SMERJ, Prof. Articulador Pedagógico CE Prof. Ernesto Faria /SEEDUC-RJ. vitornca@globo.com

3 O assunto foi tratado na dissertação de mestrado apresentada ao PPGEB/CAp-UERJ: Caetano, Vitor Nunes. Humanização e desumanização na escola: o que dizem os gostos e desgostos na tecitura complexa dos sentidos produzidos sobre as práticas escolares / Vitor Nunes Caetano. - 2016. 
humanização dos cuidados pediátricos; e a situação da relação médico-paciente relacionada à humanização da assistência às crianças vitimadas por abuso sexual.

Na sua parte terceira, "Humanização nos cuidados da saúde da mulher", os quatro artigos que se seguem tratam da questão da humanização da assistência à saúde da mulher, abordando aspectos de gênero e temáticas relativas ao parto, à prática do aborto e ao atendimento de mulheres que vivem com Aids.

Embora o livro organizado pela professora Deslandes se dedique a discutir, uma questão que é específica do campo da saúde, (neste caso, a humanização relacionada às práticas do cuidar), pensamos que a área de educação pode se beneficiar em muito das proposições e reflexões feitas pelos autores. Isto porque, guardadas as especificidades, é possível encontrar similaridades entre esses campos (Saúde e Educação), no tocante as diversas situações geradoras de problemas que são tratados em processos de pesquisa em saúde, cujo objeto seja a humanização. Daí a recomendação da obra. 